\title{
Social Media Usage in Improving English Language Proficiency from the Viewpoint of Medical Students
}

\author{
Minwuyelet Andualem Desta' \\ Melaku Bayu Workie (D) \\ Destaw Bayabel Yemer' \\ Chalachew Yenew Denku ${ }^{2}$ \\ Meslo Sema Berhanu ${ }^{3}$ \\ 'Department of English Language and \\ Literature, Debre Tabor University, \\ Debre Tabor, Amhara, Ethiopia; \\ ${ }^{2}$ Department of Public Health, College of \\ Health Sciences, Debre Tabor University, \\ Debre Tabor, Amhara, Ethiopia; \\ ${ }^{3}$ Department of Medical Laboratory \\ Sciences, College of Health Sciences, \\ Debre Tabor University, Debre Tabor, \\ Amhara, Ethiopia
}

Background: In the world today, many people use various communication technologies, like as computer-aided equipment, the internet, and so on. In information communication technologies, people use social media as one of the tools with which to exchange their ideas in everyday communications. Hence, the present study aimed at examining social media usage in improving English language proficiency from the viewpoint of medical students among Ethiopian public university students.

Methods: A descriptive survey design was employed since the purpose of this study was to gain detail information about social media usage in improving English language proficiency from the viewpoint of medical students. Hence, the researchers intended to use a quantitative approach. This is because a quantitative methodology helps researchers calculate the results more easily and avoid the difficulties which a qualitative approach might entail.

Results: The reports obtained from respondents showed that social media (SM) platforms have many advantages in improving medical learners' English understanding in the process of EFL learning. It positively affects them in improving their level of English proficiency. Gender not only influenced the attitude of students in using social media for learning English but also improved their proficiency in the process of language learning. Even if gender differences exist in nature, significant differences in the viewpoint of male and female students regarding social media (SM) usage in enhancing their English proficiency were not observed. The majority of the respondents strongly agreed that social media use plays a dominant role in improving English proficiency.

Conclusion: In the English language learning-teaching process, social media platforms have many advantages in enhancing medical students' English proficiency in their own learning and teaching practices. Gender did not influence the attitude of students in using social media for learning English or improve their proficiency in the process of language learning.

Keywords: attitude, EFL, medical students, social media

\section{Introduction}

Information communication technologies are vital in all walks of life. In the world today, many people use various communication technologies, such as computer-aid ed equipment, the internet, and the like. ${ }^{10,20}$ People use social media as one tool to exchange ideas in their everyday communications. ${ }^{24}$ New technologies have played an important role for human beings not only in how they communicate but also in improving learners' social behavior.
Correspondence: Minwuyelet Andualem Desta

Po. Box-272

Tel +25I-9 2l 290213

Email minwuye2008@gmail.com 
In this regard, Tuckman explained that learners are no longer little versions (variations) of people as they may have been in previous decades. ${ }^{29}$ Interactions through ICT tools and computer and mobile applications like Facebook, and Twitter make learners more active in their own lives. $^{25,29}$ Learners who originated from countries in which English is used as a foreign language (eg Ethiopia) have changed their views on learning information communication technologies. ${ }^{16}$ They can socialize with other students who speak the English language well (naïvely or as their first language) and those who have developed their competency in ESL. Social media provide a number of platforms that help students to create and grasp ideas andinteract with large audiences. ${ }^{18}$ In the world today, most of the non-English speaking countries, such as Ethiopia, have adopted different kinds of learning programs that assist learners to learn the English language. ${ }^{31}$ Thus, having knowledge of the English language through using new technology (eg Facebook, wikis, etc.) is one possible way to learn, among others. ${ }^{14,18}$

Within English as a foreign language educational settings, information and communication technologies (ICT) have initiated new educational practices that can be justifiable methods of language learning and teaching. This is because it is important to deduce whether or not such technologies have been viewed as an active force by teachers and students. The present study explored the role of social media (SM) platforms on students' English language proficiency, whereby interactions on SM may affect learners in terms of forming positive or negative views on EFL (English as a foreign language) learning. ${ }^{7,33}$

Research studies have shown that adopting web-based communication tools is vital at all educational levels in the world (ie English-speaking countries and non-English speaking countries). For example, Girma conducted a study on potential uses of social media in educational practices. $^{8}$ He examined the opportunities that social media usage provides for today's neo-millennial students and found that learners have developed their own learning styles through using different interactive media and reading and commenting on other people's posts on social networking sites. ${ }^{8}$

Likewise, Taye conducted a study on the advantages of SM for teachers' language teaching at Unity University College, Addis Ababa, Ethiopia. He found that teachers who seek to utilize social media make their students take an active role in their own everyday learning. ${ }^{28}$ In line with this, the Ethiopian Ministry of Education pointed out that higher educational institutions (HEIs) still rely on traditional platforms, like learning management systems, that do not capitalize on the pedagogical benefits of $\mathrm{SM}^{21}$ Identifying the advantages that SM offers in terms of in shifting the viewpoint of students regarding English language learning in non-English-speaking countries, like Ethiopia, has become an essential research subject. ${ }^{33}$ This is because it is useful in communicating and sharing of knowledge because SM is easier to use and has a wider reach than other sources. ${ }^{13}$

Moreover, Kline conducted research on the overall outcomes of SM on pupils' learning at Amhara colleges of teacher education. He found that learners may use SM sources like WhatsApp, Facebook and other social networking sites to improve their learning, in both picture form and messages/texts. ${ }^{9,15}$ SM plays a dominant role in learning since it provides opportunities for learners to improve their learning skills. ${ }^{4}$

This current study tried to assess the viewpoint of medical students regarding social media usage in improving their English proficiency in EFL learning. It attempted to unravel how using SM tools enables learners to perceive their English language proficiency, and whether or not it positively/negatively affects their English language learning. This was to discover whether or not medical EFL learners improve their English language proficiency through social media usage. Moreover, it also questioned whether gender influences students' views on social media use and, consequently, their academic performance. Thus, in Ethiopia, social networking sites have particularly become integral parts of higher education students' lives and learning. ${ }^{11,22}$

However, as much as this area grasps researchers' attention in developed countries, it has been an unexplored area in developing countries like Ethiopia. ${ }^{22}$ It still remains hardly explored by local researchers. The researchers' aim was to deduce social media usage in the English language learning-teaching process and identify university students' viewpoints regarding its contributions to enhancing their English language competency. This study, therefore, aimed at examining the role of social media usage in improving English language proficiency from the viewpoint of medical students among Ethiopian public university students. The study attempted to answer the basic research questions stated below: 
[1] What are the medical students' viewpoints on social media usage in improving their English language proficiency?

[2] Is there any statistically significant difference that can be ascribed to gender (male and female students) in the viewpoints of respondents regarding learning English through using social media?

\section{Method}

Design

TThe researchers employed a descriptive survey design since the purpose of this study was to gain detailed information about SM usage in improving English language proficiency from the viewpoint of medical students. Hence, the researchers used a quantitative approach because it helped them calculate the results more easily and avoid the difficulties which a qualitative approach might produce. ${ }^{17}$

\section{Research Site and Population}

The study was conducted at Debre Tabor University in Ethiopia. It was chosen based on its convenience for data collection. Also, doing research in the home university saved time and finance outlays as the researchers worked at the university too. The research participants were medical students taking English Language Skills courses. Second year and above medical students were targeted because they took more than one English language course during their six years' study as, in Ethiopia, the English language is the learners' target language for studying medicine. There were 99 (41 male and 58 female) second year and above medical students at Debre Tabor University in the 2019/2020 academic year. As the number of participants was manageable, the researchers found the comprehensive sampling technique more convenient. Thus, data were generated from 99 respondents in the second semester of the 2019/2020 academic year.

\section{Instruments}

The researchers used a self-administered questionnaire as the data gathering instrument, which was designed to assess students' viewpoints regarding the role of SM usage in enhancing their English proficiency. Thus, a fivepoint Likert scale ranging from strongly agree to strongly disagree was used. The researchers developed the questionnaire based on research objectives, and used some procedures to ensure its validity and reliability. To ensure its validity, the questionnaire was given to two volunteer educational psychologists from Debre Tabor University because they were expected to have more experiences on research. Thequestionnaire's reliability coefficient, in contrast, was computed using Cronbach's alpha.

\section{Data Analysis}

The researchers employed a descriptive research design. Hence, the researchers used descriptive statistics like frequency, percentages, etc. to analyze data obtained from questionnaires and inferential statistics like $t$-tests, using SPSS version 20. Here, $t$-tests were used to check whether or not statistically significant differences existed between genders (male/female learners) in how they perceive English language learning via social media usage. The statistical significance values were computed at 0.05 .

\section{FindingsFindings}

Medical Students' Viewpoints regarding SM Usage in Improving Their English Language Proficiency

So as to know students' feeling about social media usage in the improvement of their English language proficiency, percentages and frequencies were used to analyze their responses to the questionnaires. The findings are summarized in Tables 1-5. Most of the students strongly agreed that social media was a good platform for student learning.

Table I Social Media is a Useful Platform to Improve Medical Students' English Proficiency

\begin{tabular}{|l|l|l|l|l|l|l|l|l|l|l|}
\hline \multirow{2}{*}{ Valid } & \multicolumn{10}{|c|}{ Responses } \\
\cline { 2 - 12 } & \multicolumn{1}{|l|}{ SA } & \multicolumn{1}{|l|}{ A } & \multicolumn{1}{|l|}{ UD } & \multicolumn{2}{|l|}{ DA } & \multicolumn{2}{|l|}{ SD } \\
\cline { 2 - 11 } & F & $\%$ & F & $\%$ & F & $\%$ & F & $\%$ & F & $\%$ \\
\hline & 13 & 13.1 & 54 & 54.5 & 2 & 2.0 & 27 & 27.3 & 3 & 3.0 \\
\hline
\end{tabular}

Abbreviations: SA, strongly agree; $A$, agree; UD, undecided; DA, disagree; SD, strongly disagree; $F$, frequency.

Table 2 Social Media Increases Medical Students' Confidence in the Use of the English Language

\begin{tabular}{|l|l|l|l|l|l|l|l|l|l|l|l|}
\hline Valid & \multicolumn{9}{|c|}{ Responses } \\
\cline { 2 - 11 } & \multicolumn{1}{|c|}{ SA } & \multicolumn{1}{|l|}{ A } & \multicolumn{2}{|l|}{ UD } & \multicolumn{2}{|l|}{ DA } & \multicolumn{2}{|l|}{ SD } \\
\cline { 2 - 11 } & F & $\%$ & F & $\%$ & F & $\%$ & F & $\%$ & F & $\%$ \\
\hline & 3 & 3.0 & 62 & 62.6 & 12 & 12.1 & 12 & 12.1 & 10 & 10.1 \\
\hline
\end{tabular}

Abbreviations: SA, strongly disagree; A, agree; UD, undecided; DA, disagree; SD, strongly disagree; F, frequency. 
Table 3 Social Media Helps Medical Students to Grasp/Create Good Ideas in the English Language

\begin{tabular}{|l|l|l|l|l|l|l|l|l|l|l|l|}
\hline Valid & \multicolumn{10}{|c|}{ Responses } \\
\cline { 2 - 12 } & \multicolumn{1}{|l|}{ SA } & \multicolumn{1}{|l|}{ A } & \multicolumn{2}{|l|}{ UD } & \multicolumn{2}{|l|}{ DA } & \multicolumn{2}{|l|}{ SD } \\
\cline { 2 - 12 } & F & $\%$ & F & $\%$ & F & $\%$ & F & $\%$ & F & $\%$ \\
\hline & 12 & 12.1 & 53 & 53.5 & 3 & 3.0 & 31 & 31.3 & - & - \\
\hline
\end{tabular}

Abbreviations: SA, strongly disagree; A, agree; UD, undecided; DA, disagree; SD, strongly disagree; F, frequency.

Table 4 Social Media Helps Learners to Minimize Their Level of Anxiety in Using the English Language

\begin{tabular}{|l|l|l|l|l|l|l|l|l|l|l|l|}
\hline \multirow{3}{*}{ Valid } & \multicolumn{9}{|c|}{ Responses } \\
\cline { 2 - 12 } & SA & \multicolumn{1}{|l|}{ A } & \multicolumn{2}{|l|}{ UD } & \multicolumn{2}{|l|}{ DA } & \multicolumn{2}{|l|}{ SD } \\
\cline { 2 - 12 } & F & $\%$ & F & $\%$ & F & $\%$ & F & $\%$ & F & $\%$ \\
\hline & 22 & 22.2 & 66 & 66.7 & 2 & 2.0 & 7 & 7.1 & 2 & 2.0 \\
\hline
\end{tabular}

Abbreviations: SA, strongly disagree; A, agree; UD, undecided; DA, disagree; SD, strongly disagree; F, frequency.

Table 5 Social Media Positively Affects Learners in Their English Language Learning

\begin{tabular}{|l|l|l|l|l|l|l|l|l|l|l|}
\hline \multirow{2}{*}{ Valid } & \multicolumn{10}{|c|}{ Responses } \\
\cline { 2 - 11 } & \multicolumn{1}{|l|}{ SA } & \multicolumn{1}{|l|}{ A } & \multicolumn{2}{|l|}{ UD } & \multicolumn{2}{|l|}{ DA } & \multicolumn{2}{|l|}{ SD } \\
\cline { 2 - 11 } & F & $\%$ & F & $\%$ & F & $\%$ & F & $\%$ & F & $\%$ \\
\hline & 27 & 27.3 & 57 & 57.6 & 7 & 7.1 & 6 & 6.1 & 2 & 2.0 \\
\hline
\end{tabular}

Abbreviations: SA, strongly disagree; A, agree; UD, undecided; DA, disagree; SD, strongly disagree; $F$, frequency.

This tends to agree with the finding of Omar, that SM enables learners find resources and distribute them to others. According to him, social media may force students to waste time on their learning activities rather than using the constructive, cooperative and real learning opportunities that such platforms offer ${ }^{23}$ because, by nature, SM is attractive or appealing to the senses. ${ }^{23}$

As the data in Tables 1 and Figure 1 shows, the majority of respondents $(54.5 \%)$ strongly agreed that social media is a good platform to improve medical students' English language proficiency. In contrast, 3\% of respondents strongly disagreed that social media is not a useful platform to enhance students' English language competency. This is because, when students use Facebook, they waste so much time and forget their learning aim.

As presented in Tables 2 and Figure 2, 62.6\% of respondents agreed that social media is a very important learning tool to promote students' confidence in every aspect of their studies in general and on the use of the English language in particular. Three percent of respondents, on the other hand, strongly disagreed that social media increases medical students' confidence in using the English language.

As indicated in Tables 3 and Figures 3, 53.5\% of participants agreed that social media helps learners to grasp/create good ideas in the English language. Participants responded that, when students use SM as a learning tool, they are able to create good ideas in the English language and communicate them to others. However, $31.3 \%$ of respondents disagreed that SM helps learners to create or grasp good ideas in the English language in all learning-teaching situations. Moreover, $12.1 \%$ of respondents strongly agreed that social media helps medical students to grasp/create good ideas in the English language.

As the data presented in Tables 4 and Figure 4 show, $66.7 \%$ of respondents agreed that social media enables learners to minimize their level of anxiety in using the English language. This is because, in non-Englishspeaking countries in general and Ethiopia in particular, at any grade level, most of the students are afraid to express their ideas using the English language. In contrast, $2 \%$ of respondents strongly disagreed that SM helps learners to minimize their level of anxiety in using the English language. From here, one can possibly say that SM used as a learning tool does improve students' English language competency by reducing their level of anxiety.

As shown in Tables 5 and Figure 5, 57.6\% of respondents agreed that SM positively affects learners EFL learning because it encourages them to reflect on their ideas using the English language inside and outside the classroom. In line with this, 27 respondents (27.3\%) strongly agreed that it positively affects learners in their English language learning. This is because it creates room for students to grasp ideas in English using the skills gained in the EFL learning-teaching process. In contrast, $6.1 \%$ of students disagreed that SM positively affects students in their English language learning. From this, one can conclude that SM greatly affects learners' attitudes toward their English language learning.

As shown in Table 6, no significant differences were observed between students' viewpoints on the basis of gender $(\mathrm{M}=$ males, 3.5, females, $3.6 ; 57.1 \%$ and $41.07 \%$, respectively; $\mathrm{p}=0.34, \mathrm{r}=0.19$ ). From this, one can possibly claim that male and female medical students 
10

0

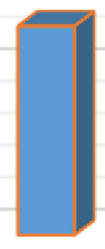

F

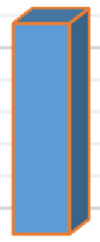

$\%$

SA

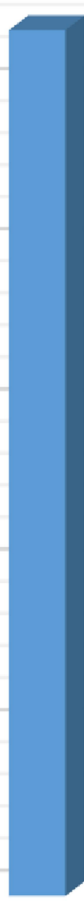

F

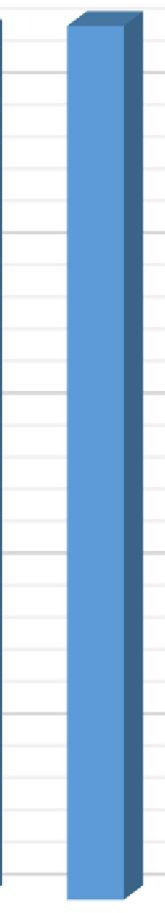

$\%$

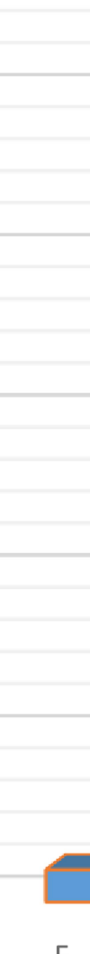

UD

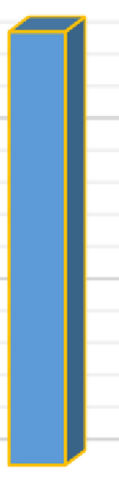

F

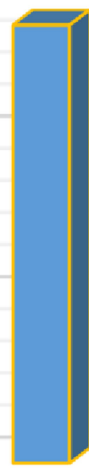

$\%$

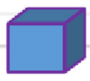

F
A

Responses

Figure I Social media is a useful platform to improve medical students' English proficiency.

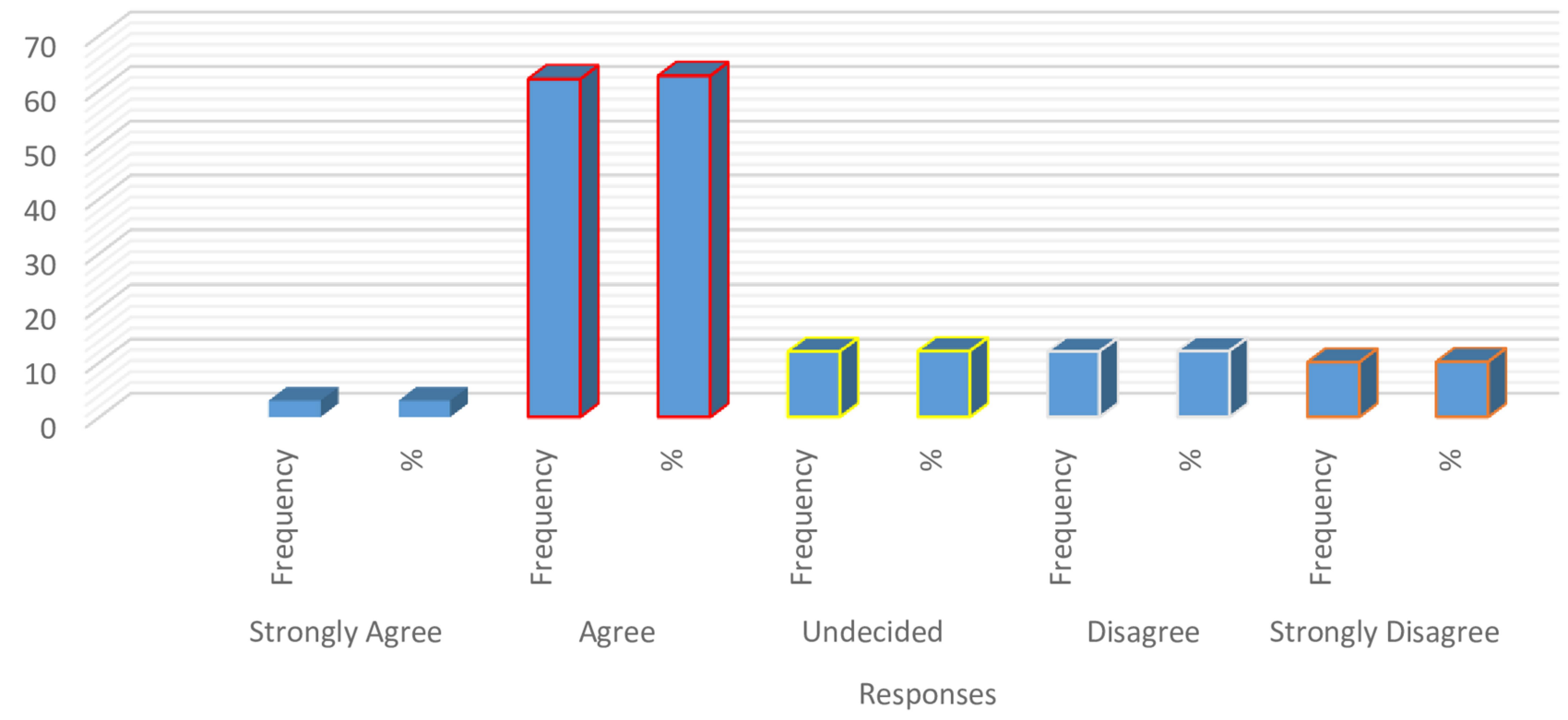

Figure 2 Social media increases medical students' confidence in use of the English language. 
60

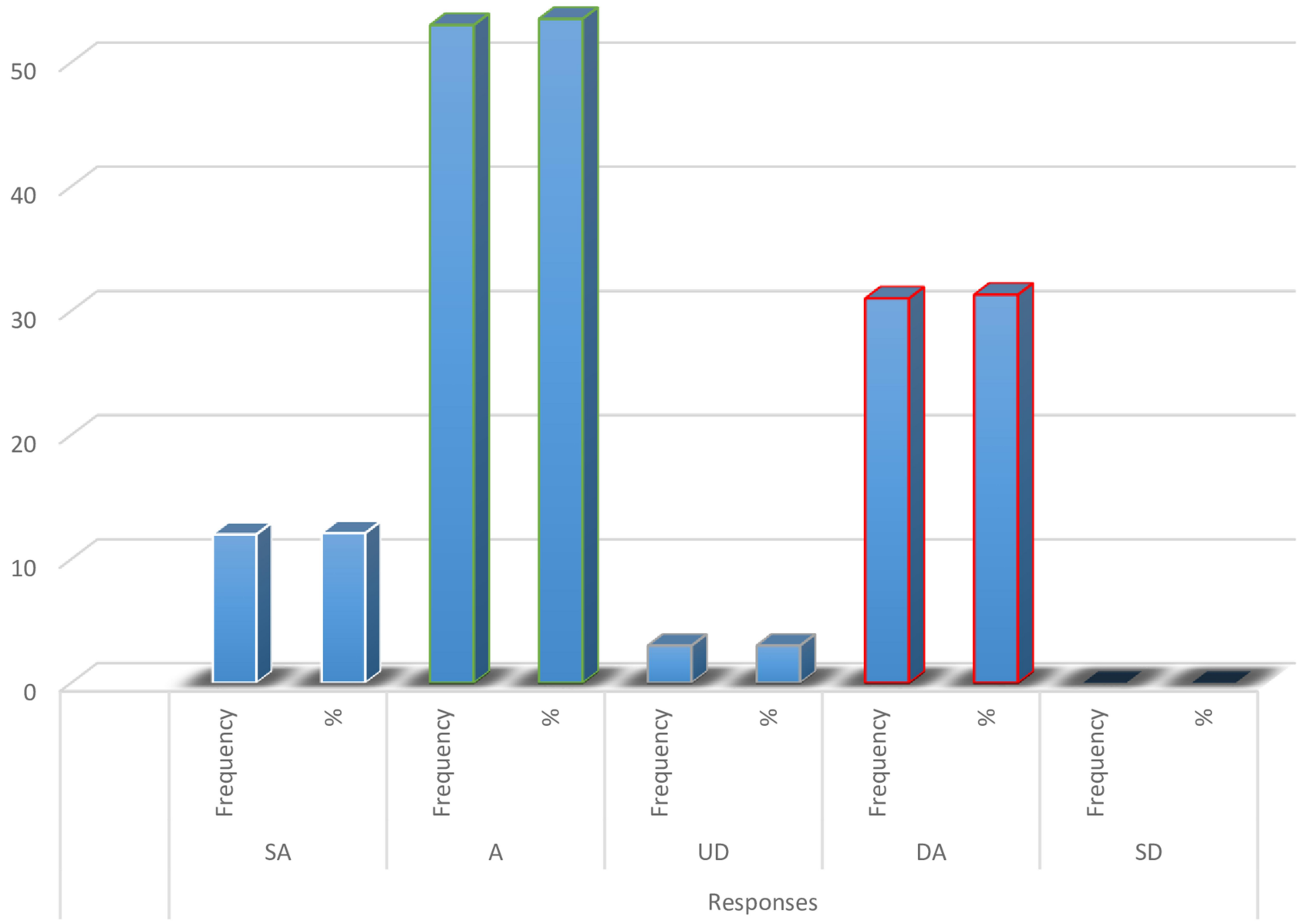

Figure 3 Social media helps medical students to grasp/create good ideas in the English language.

held similar views regarding the influence of SM usage on their English language learning.

\section{Discussion}

The main purpose of this study was to examine social media usage in improving students' English language proficiency from the viewpoint of medical students. The study explored the impacts of social media on medical students' attitudes towards English language learning from their perspectives. The first research question was proposed to identify views of medical students regarding social media usage in improving their English proficiency in their own English language learning and teaching practices. It was intended to unravel SM usage and its influence on EFL learners' views regarding their English language learningteaching process. Our results revealed that most medical students felt that they benefited from social media usage.
Our results also showed that social media helps to improve learners' understanding of how to use their English language skills (ie macro and micro English language skills) and ability to practice inside and outside the classroom in the real world. The statistical data from all sources deduced that SM platforms offer many advantages in terms of improving medical learners' English understanding in the process of EFL learning. This finding is congruent with other research identifying that learners may promote their EFL fluency by reading constructive comments on other people's posts on Twitter, Telegram, etc. ${ }^{3,26}$ Also, the finding supports the statement of Jarer that most social networking sites utilize English as the principal language, even those that have been customized. ${ }^{12}$ Thus, those networking sites help beginners learning first-level (basic) English language skills. ${ }^{12}$ 
70

60

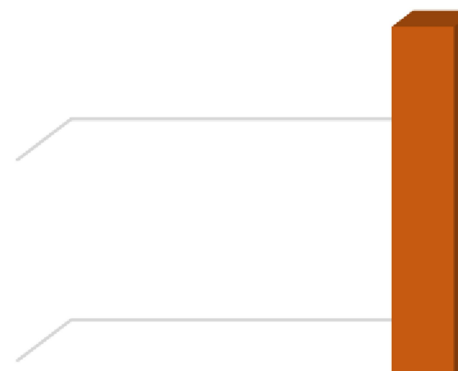

50

40

30

20

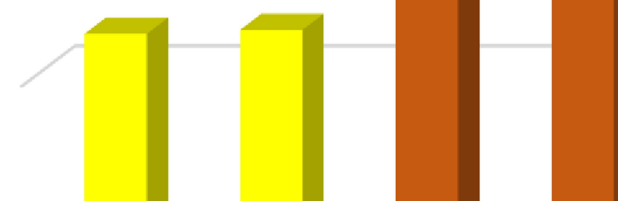

10

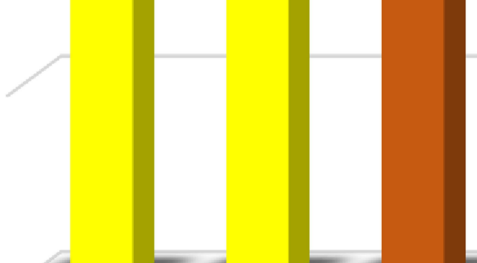

0

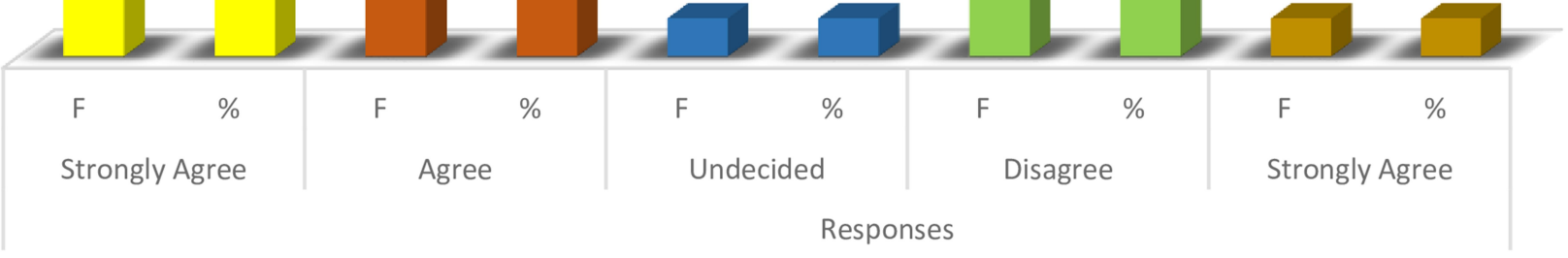

Figure 4 Social media helps learners to minimize their level of anxiety in using the English language.

In sum, using SM offers many advantages for improving medical students' understanding of and proficiency in English, and positively influences their attitude toward English language learning and teaching. It encourages the idea that SM has a place in teaching/learning based on the understanding that learners derive their level of competency from creating connections with others. ${ }^{27}$ Moreover, students reported that SM improves their level of understanding and performance in their EFL learning. It also enhances learners' awareness regarding listening, speaking, reading, writing, grammar, vocabulary skills, etc., which helps them in their everyday communications. ${ }^{6,30}$ Moreover, Miangah stated that communication using $\mathrm{SM}$ is an effective way to improve learning of the English language. ${ }^{19}$

Social media usage positively affects learners' understanding of English. In line with this, the responses gained from respondents showed that most of them strongly agreed that SM inspires them to reflect on their ideas using the English language inside and outside the classroom. This idea tends to agree with the findings of 


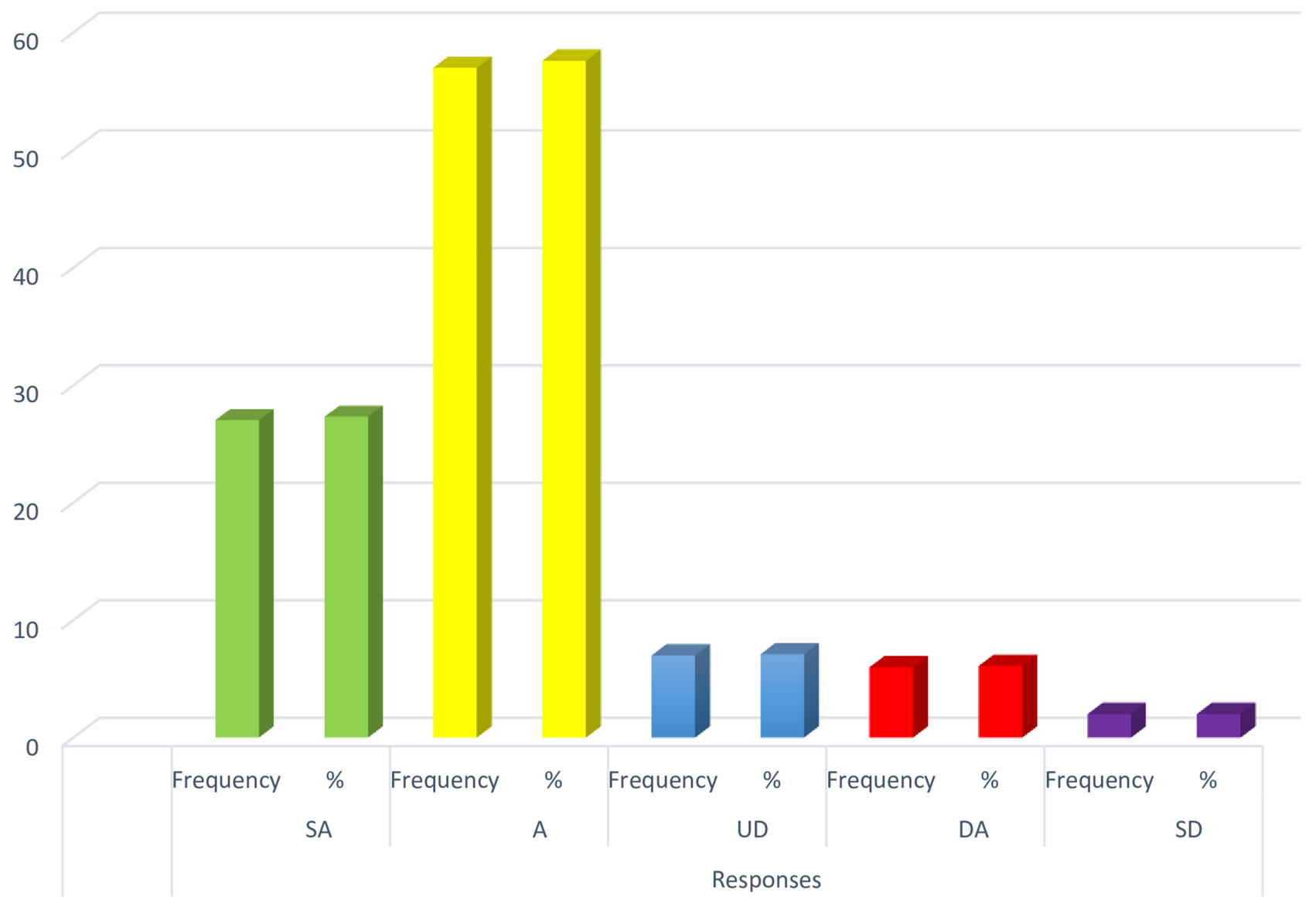

Figure 5 Social media positively affects learners in their English language learning

a number of individuals who feel that SM provides opportunities to use the target language (English) in their own learning practices. ${ }^{23,32}$ Furthermore, the second research question was intended to identify whether or not a significant difference exists between the viewpoints of male and female learners regarding learning English through SM usage. As the data in Table 6 shows, there were no significant differences in the viewpoints of male and female learners.

From this, it is possible to deduce that gender did not influence either views on utilizing social media in EFL learning or improving proficiency in the process of language learning-teaching. This idea is supported by the

Table 6 Mann-Whitney Test

\begin{tabular}{|l|l|l|l|l|l|l|}
\hline \multicolumn{7}{|l|}{ Mann-Whitney Test } \\
\hline Students' attitude & \multicolumn{2}{|l|}{ G } & \multicolumn{2}{l|}{ MR } & TR & SD \\
\cline { 2 - 7 } & F & M & F & M & 7288 & 0.34 \\
& 58 & $4 I$ & 57.1 & 41.07 & & \\
\hline
\end{tabular}

Abbreviations: G, gender; MR, mean rank; TR, total rank; SD, significance difference; $F$, female; $M$, male. findings of Aidom, that is, even if gender differences exist in nature, they are not reflected in learning, studying, working and so on. ${ }^{2,5}$

\section{Conclusion}

On the basis of our overall findings, we reached the following conclusions. In the English language learningteaching process, social media platforms have many advantages in terms of enhancing medical students' English proficiency. SM can broaden their ways of communication and levels of interaction, etc. Most of the medical students strongly agreed that SM usage enables them to improve their English language proficiency, and it can guide them on how to use and practice the target language (English) in their everyday walks of life. As their reports disclosed, learners are highly motivated to use social media in English learning since it offers opportunities to make everything clear to them.

Learners benefited from SM usage in terms of improving their macro (ie listening, speaking, reading and writing) and micro (ie grammar, vocabulary, pronunciation) English 
language skills. Moreover, gender did not influence attitude to using SM for learning English or improving their proficiency in the process of language learning. Thus, even if gender differences exist in nature, they are not reflected in views on learning English via SM.

\section{Abbreviations}

EFL, English as a foreign language; ESL, English as a second language; SM, social media.

\section{Data Sharing Statement}

The datasets used during the present study are available from the corresponding author on reasonable request after completion of data publication.

\section{Ethics Approval and Consent Statement}

This study was approved by the research ethics committee of Debre Tabor University, Department of English Language and Literature (Ref. dtu.837.En./01/13). The objectives of the study were explained to the students and written informed consent obtained from all of them before distributing the data. The study was conducted in accordance with the Declaration of Helsinki.

\section{Acknowledgments}

The authors would like to extend their gratitude to the Department of English Language and Literature, University of Debre Tabor, for their material assistance in this study, although the department was not involved in the study. Next, the authors would like to give great thanks to all participants who cooperated with them in the data collection process.

\section{Author Contributions}

All authors made substantial contributions to conception and design, acquisition of data, or analysis and interpretation of data; took part in drafting the article or revising it critically for important intellectual content; agreed to submit to the current journal; gave final approval of the version to be published; and agree to be accountable for all aspects of the work.

\section{Disclosure}

The authors declare no conflicts of interest in this work.

\section{References}

1. Abu S. Students' perceptions of English language learning in the Facebook context. Teach English Technol. 2018;15(4):60-75.
2. Aidom P. The development of virtual learning communities. In: Hiltz SR, Goldman R, editors. Learning Together Online: Research on Asynchronous Learning Networks. New York, NY: Hampton Press; 2017:141-163.

3. Ahmad A. Social media for language learning, improvement for teaching and learning and student progress. 2013. doi:10.1311/h. asl.2110.02.003

4. Bahrain T. Speaking fluency: technology in EFL context or social interaction in ESL context. Stud Literature Lang. 2018;2(2):162-168.

5. Chun M. Technology and higher education: opportunities and challenges for the new era. In: Altbach PG, Berdahl RO, Gum PJ, editors. American Education in the 21st Century. Baltimore, MD: Johns Hopkins University Press; 2007:255-284.

6. Cowins S Spelling and grammar in the age of social media. Math Genie. 2017. Available from: https://www.mathgenie.com/Blog/spel ling-grammar. Accessed January 22, 2018.

7. Elyas M. Online Communication and Collaboration: A Reader. Abingdon: Rutledge; 2016.

8. Girma M. The examination of potential uses of social media in education. Elt J. 2012;51(2):183-185. doi:10.1072/e.1.t/ccm015

9. Gorsuch R. Factor Analysis. 2nd ed. Hillsdale, NJ: Lawrence Erlbaum Associates; 1983.

10. Haridakis P, Hanson G. Social interaction and co-viewing with YouTube: blending mass communication reception and social connection. J Broadcast Electron Media. 2009;53(2):317-335. doi:10.1080/08838150902908270

11. Heyam A. The influence of social networks on students' academic performance. J Emerg Trends Comp Inf Sci. 2014. Available from:

12. Jarer A Students' attitudes towards using social media to support learning. Doctoral dissertation. 2017.

13. Kamnoetsin T Social media use: a Critical analysis of Facebook's impact on collegiate EFL students' English writing in Thailand. Seton Hall University Dissertations and Theses (ETDs), 2014 Available from: www.scholarship.shu.edu/dissertations/2059. Accessed Febraury 5, 2019.

14. Kirschner P, Karpinski A. Facebook and academic performance. Comp Human Behav. 2010;26(3):1237-1245. doi:10.1016/j.chb.2010.03.024

15. Kline P. Psychometrics and Psychology. London: Cadaveric Press; 1979.

16. Kolan T. Pronunciation instruction through Twitter: the case of commonly mispronounced words. Lang Learn. 2014;30(7):511-552. doi:10.1080/08599221.2014.1340307

17. Kothari C. Research Methodology: Methods and Techniques. 2nd Revised ed. New Age International Publishers: New Delhi; 2004.

18. Lin TB, Li JY, Deng F, Lee L. Understanding New media literacy: an explorative theoretical framework. Educ Technol Soc. 2013;16 (4): 160170 .

19. Miangah T, Nezarat A. Mobile-assisted language learning. Int J Distributed Parallel Syst. 2012;3(1):309-319.

20. Miller D. Teaching ESL through SMS: prospects and problems in Nigeria. English Linguistics Res. 2016;8(1):1-7.

21. Ministry of Education. Social Media Report. Addis Ababa: George Printing Press; 1999.

22. Nebiat N, Girum K. Relationship between Facebook Practice and Academic Performance of University Students. Asian J Humanities Social Sci. 2014;2(2):31-37.

23. Omar H. ESL learners' interaction in an online discussion via Facebook. Asian Soc Sci. 2012;8(11):67-74. doi:10.5539/ass.v8n11p67

24. Papas K. Users of the world, unite! The challenges and opportunities of social media. Bus Horiz. 2013;53(1):59-68.

25. Pavlik H The Impact of Facebook and Twitter 2015. 1(2):3-7. Available from:: Http://Unpan1.Un.Org/Intradoc/Groups/Public/ Documents/Dsg/Unpan040861.Pdf. Accessed. 2015.

26. Shih R. Can Web 2.0 technology assist college students in learning English writing? Integrating Facebook and peer assessment with blended learning. Austr J Educ Technol. 2011;27(5):829-845. 
27. Siemens G. Connectivism: a Learning Theory for the Digital Age, 2016. Available from: www.elearnspace.org/Articles/connectivism. htm. Accessed March 5, 2017.

28. Taye K. The Advantages of Social Media on Language Learning/ Teaching Context. Unity University College, A.A; 2016. Available from: http://jcmc.indiana.edu/vol4/issue8/bodi.ellison.html. Accessed May 4, 2021.

29. Tuckman H. Teacher effectiveness and students' performance. J Econ Educ. 2018;7(1):34-39. doi:10.1080/00220485.1975.10845419

30. Vygotsky L. Mind in Society: The Development of Higher Psychological Processes. Cambridge, MA:: Harvard University Press; 1978.
31. Wang Q, Chen W, Liang Y. The Effects of Social Media on College Students. Johnson \& Wales University; 2011.

32. Wang, Wang AT, Sandhu NP, et al. Using social media to improve continuing medical education: a survey of course participants. Mayo Clinic Proc. 2012;87(12):1162-1170. doi:10.1016/j.mayocp.2012.07.024

33. Yagi T. Mobile social media challenges digital natives in EFL learning. J Educ Inst Stud World. 2017;4(4):49-53.

34. Zhang D. A history and Attitudes. Dales Pocket. 2009;5(7). http:// www.rebeccahistory.net/essays/webloghistory.html.

\section{Publish your work in this journal}

Advances in Medical Education and Practice is an international, peerreviewed, open access journal that aims to present and publish research on Medical Education covering medical, dental, nursing and allied health care professional education. The journal covers undergraduate education, postgraduate training and continuing medical education including emerging trends and innovative models linking education, research, and health care services. The manuscript management system is completely online and includes a very quick and fair peer-review system. Visit http://www.dovepress.com/testimonials.php to read real quotes from published authors. 